Royal Netherlands Institute for Sea Research

This is a postprint of:

Kool, D.M., Talbot, H.M., Rush, D., Ettwig, K. \& Sinninghe Damsté, J. S. (2014). Rare bacteriohopanepolyols as markers for an autotrophic, intra-aerobic methanotroph. Geochimica et Cosmochimica Acta, 136, 114-125

Published version: $\underline{\text { dx.doi.org/10.1016/i.gca.2014.04.002 }}$

Link NIOZ Repository: $\underline{w w w . v l i z . b e / n l / i m i s ? m o d u l e=r e f \& r e f i d=239932 ~}$

[Article begins on next page]

The NIOZ Repository gives free access to the digital collection of the work of the Royal Netherlands Institute for Sea Research. This archive is managed according to the principles of the Open Access Movement, and the Open Archive Initiative. Each publication should be cited to its original source - please use the reference as presented.

When using parts of, or whole publications in your own work, permission from the author(s) or copyright holder(s) is always needed. 


\title{
Rare bacteriohopanepolyols as markers for an autotrophic, intra-aerobic methanotroph
}

\author{
Dorien M. Kool ${ }^{1}$, Helen M. Talbot ${ }^{2}$, Darci Rush ${ }^{2}$, Katharina Ettwig ${ }^{3}$, Jaap S. Sinninghe Damsté ${ }^{1 \#}$ \\ ${ }^{1}$ NIOZ Royal Netherlands Institute for Sea Research, Department of Marine Organic Biogeochemistry, PO \\ Box 59, 1790 AB Den Burg, Texel, the Netherlands; \\ ${ }^{2}$ Newcastle University, School of Civil Engineering and Geosciences, Drummond Building, Newcastle \\ upon Tyne NE1 7RU, UK; \\ ${ }^{3}$ Radboud University Nijmegen, Institute of Water and Wetland Research, Department of Microbiology, \\ PO Box 9010, 6500 GL Nijmegen, the Netherlands. \\ \# corresponding author. Email: Jaap.Damste@nioz.nl
}

As published in: Geochim. Cosmochim. Acta 136, 114-125 (2014).

\begin{abstract}
Bacteriohopanepolyols (BHPs) and their diagenetic products, hopanoids, are of great interest for their potential as biomarker lipids in both present day environments as well as in the geological record. Specific structural features such as methylation of the A-ring, and number and type of functional groups of $\mathrm{C}_{35}$ BHPs have been held characteristic for certain groups of organisms. Here we investigated the potential presence of BHPs in the unusual anaerobic methanotroph Methylomirabilis oxyfera and another Methylomirabilis sp. Although M. oxyfera thrives in anoxic settings, it uses internally produced molecular oxygen (from nitrite) for the oxidation of methane. We found that Methylomirabilis spp. synthesizes bacteriohopanehexol (BHP-hexol), -pentol, and -tetrol, and 3-methyl derivatives of each as major BHPs. None of the C-35 amino-BHPs that are more commonly observed in methanotrophs were detected. Our findings provide the first ever account of a 3-methyl-BHP-hexol, and only the second known source organism for BHP-hexol after Alicyclobacillus acidoterrestris. As the genes required for C3-methylation seem to be exclusively present in microorganisms with an aerobic metabolism, the abundant presence of 3-methyl-BHPs in Methylomirabilis spp. denotes for the first time the potential production of 3-methyl hopanoids in anoxic environments. Furthermore, with ${ }^{13} \mathrm{C}$-labeling experiments we show that $M$. oxyfera does not assimilate methane-carbon, but rather $\mathrm{C}$ from bicarbonate $/ \mathrm{CO}_{2}$, into its BHPs. This implies that methanotroph-derived hopanoids do not necessarily exhibit a strongly depleted carbon isotopic signature, which is commonly anticipated with methanotrophy. This may have implications for the interpretation of the presence of hopanoids and their isotopic signature in the paleorecord.
\end{abstract}




\section{INTRODUCTION}

Hopanoids are widely distributed in the environment (Ourisson and Albrecht, 1992; Ourisson et al., 1979), in both recent and ancient sediments dating back as far as the Proterozoic (Brocks et al., 2005). Hopanoids are derived from biosynthetically produced $\mathrm{C}_{30}$ and the extended $\mathrm{C}_{35}$ hopanepolyols, which are commonly named bacteriohopanepolyols (BHPs), as bacteria are their only known source organisms. Both intact BHPs and their diagenetic products are used as molecular biomarkers as certain properties, such as the structure of the extended side chain of the intact BHPs or methylation of the hopanoid A-ring, have been associated with distinct groups of bacteria or specific metabolic processes. Hopanoids in general were once interpreted as evidence for oxygenated conditions, as there had been few reports of hopanoids in anaerobic organisms. This idea changed with the observation of hopanoid biosynthesis in several facultative anaerobes and fermentative bacteria (e.g. Bringer et al., 1985; Llopiz et al., 1992; Neunlist et al., 1985; Neunlist and Rohmer, 1985a), and more recently also in anaerobic cultures of anammox bacteria (planctomycetes) (Sinninghe Damsté et al., 2004), Geobacter species (Eickhoff et al., 2013; Fischer et al., 2005; Hartner et al., 2005), and sulfate reducing bacteria (SRB) of the genus Desulfovibrio (Blumenberg et al., 2006, 2009a, 2012).

Methylation at the $\mathrm{C} 2$ or $\mathrm{C} 3$ position of the A-ring of hopanoids has been thought to be characteristic for specific bacteria. C2-methylated BHPs are commonly found in cyanobacteria, for which they were initially held as specific biomarker (Summons et al., 1999), but were later found to also be produced by the anoxygenic phototroph Rhodopseudomonas palustris under strictly anaerobic conditions (Rashby et al., 2007), and the biosynthetic genes required for methylation at the C2-position were found to be present in various alpha-proteobacteria and acidobacteria as well (Ricci et al., 2013; Welander et al., 2010). C3methylation was first described in acetic acid bacteria (Rohmer and Ourisson, 1976) and subsequently in aerobic methanotrophs (Zundel and Rohmer, 1985a,b). A recent study of the taxonomic distribution of the genes encoding the (potential for) C3-methylation showed that they are widely distributed among different taxa, although their occurrence seems to be restricted to bacteria with an aerobic metabolism (Welander and Summons, 2012). This implies that the presence of C3-methylation cannot be ascribed specifically to methanotrophic activity, at least not without supporting evidence from carbon isotope studies (e.g. Jahnke et al., 1999; Summons et al., 1994), but may indeed remain a biomarker for aerobic respiration.

Structural features of the side chain of BHPs have also been associated with certain organisms. Specifically, BHPs with penta- and hexafunctionalised side chains incorporating an amine at C-35 are thought to be characteristic for methanotrophic bacteria. The pentafunctionalised 35-aminohopane31,32,33,34-tetrol (aminotetrol IIIc; see Fig. 1 for structures) is found in most methanotrophs from the alpha- and gammaproteobacteria (Talbot and Farrimond, 2007), in very small amounts in Methylacidiphilum fumariolicum SolV (a recently reported methanotroph from the phylum Verrucomicrobia) (van Winden et al., 2012), and in low levels in some SRB (Blumenberg et al. 2006, 2009a, 2012). For the hexafunctionalised 35-aminohopane-30,31,32,33,34-pentol (aminopentol IVc), the gamma-proteobacterial (also known as type I) methanotrophs are thus far the only known source organisms (Talbot and Farrimond, 2007), except for one report of trace levels in SRB (Blumenberg et al., 2012).

Here we investigated the presence and composition of BHPs in the unusual methanotroph Candidatus "Methylomirabilis oxyfera". Unlike most described methanotrophic bacteria, which are aerobic proteobacteria, M. oxyfera belongs to the NC10 phylum and lives under anoxic conditions, while it internally produces its own oxygen from nitrite (Ettwig et al., 2010). Previous analyses indicated that $M$. oxyfera has the genomic potential to produce 3-methyl hopanoids (Welander and Summons, 2012), but actual production has yet to be confirmed. As BHPs have been specifically used as biomarkers for methanotrophs (e.g. Berndmeyer et al., 2013; Coolen et al., 2008; van Winden et al., 2012; Zhu et al., 2010; Talbot et al., 2014; Wagner et al., 2014), it is interesting to determine whether M. oxyfera is also 
capable of synthesizing BHPs and could form a potential source of BHPs, including 3-methyl BHPs, previously associated with aerobic metabolism, in anoxic environments.

\section{MATERIALS AND METHODS}

\subsection{Material}

Biomass was obtained from four enrichment cultures capable of nitrite-dependent methane oxidation that had been enriched from three different environments in the Netherlands, as previously described in Kool et al. (2012). Two enrichment cultures of $M$. oxyfera originated from sediment from a freshwater ditch in the 'Ooijpolder' (Ooij-1 and Ooij-2) (Ettwig et al., 2009, 2010), the third enrichment culture of $M$. oxyfera was derived from sludge from a wastewater treatment plant in Lieshout (Luesken et al., 2011). The last enrichment culture was obtained from the peatland 'Brunssummerheide' (BRH) and constitutes another species within the genus Methylomirabilis (Zhu et al., 2012). The cultures were enriched and maintained in anoxic sequencing batch reactors under constant temperature conditions, as described previously (Ettwig et al., 2009; Luesken et al., 2011; Zhu et al., 2012), and all enrichment cultures oxidized methane anaerobically with nitrite at the point of sampling at a relatively constant level of activity.

Biomass of enrichment culture Ooij-1 was used for incubation experiments with ${ }^{13} \mathrm{C}$-labeled substrates as described elsewhere (Rasigraf et al., 2014). Briefly, M. oxyfera biomass was incubated with either ${ }^{13} \mathrm{C}$-labeled $\mathrm{CH}_{4}$ or ${ }^{13} \mathrm{C}$-labeled bicarbonate (99 atom\%). The ${ }^{13} \mathrm{C}_{-} \mathrm{CH}_{4}$ treatment also contained (unlabelled) bicarbonate, and the treatment with ${ }^{13} \mathrm{C}$-bicarbonate also received $\mathrm{CH}_{4}$ as energy source. A control was included with ${ }^{13} \mathrm{C}$-bicarbonate without $\mathrm{CH}_{4}$, and as a reference biomass was also incubated with unlabelled $\mathrm{CH}_{4}$ and unlabelled bicarbonate. Two experimental replicates were included for each treatment. Methane and nitrite consumption were monitored over the course of the incubation $(24 \mathrm{~h})$ and were similar for all experiments (Rasigraf et al., 2014). The C isotopic enrichments of M. oxyfera hopanoids in the labelling treatments were compared to the $\mathrm{C}$ isotope signature of the reference.

In addition to the enrichment culture biomass, environmental samples from a soil profile were investigated. These samples were taken from a peatland (Brunssummerheide; BRH), where the most recent enrichment culture originated from. A soil profile was sampled from 51 to $102 \mathrm{~cm}$ depth, divided into nine sections (i.e. $51-60 \mathrm{~cm}, 5 \mathrm{~cm}$ increments from 60 to $95 \mathrm{~cm}, 95-102 \mathrm{~cm}$ ) (Zhu et al., 2012), spanning the zone from no to peak anaerobic methanotrophic activity.

\subsection{Hopanoid analyses}

\subsubsection{Conversion of BHPs to hopanols}

Total lipid extracts (TLE) were obtained by sonication ( $\mathrm{x} 4$ ) of freeze dried biomass (ca. $0.5 \mathrm{mg}$ ) with ca. $1 \mathrm{~mL}$ DCM:MeOH (2:1 v/v). After each sonication the mixture was centrifuged and the supernatants were collected and dried over $\mathrm{Na}_{2} \mathrm{SO}_{4}$ and further under a continuous nitrogen flow. The dried TLE were treated with periodic acid and subsequently with sodium borohydride to convert BHPs to more readily analysable terminal alcohols by cleaving the $\mathrm{C}-\mathrm{C}$ bonds of neighbouring polyols (Rohmer et al., 1984). Periodic acid (30 $\left.\mathrm{mg} \mathrm{H}_{5} \mathrm{IO}_{6}\right)$ was added to the extract in $1 \mathrm{~mL}$ tetrahydrofuran:bidistilled water $(8: 1, \mathrm{v} / \mathrm{v})$ and the mixture was stirred for $1 \mathrm{~h}$ at room temperature. The extract was washed with DCM (x3), dried over a $\mathrm{Na}_{2} \mathrm{SO}_{4}$ and further under $\mathrm{N}_{2}$. Sodium borohydride $\left(20 \mathrm{mg} \mathrm{NaBH}_{4}\right.$ in $\left.1 \mathrm{ml} \mathrm{MeOH}\right)$ was then added to the dried extract and the mixture was stirred for $1 \mathrm{~h}$ at room temperature. Subsequently $1 \mathrm{~mL} 200 \mu \mathrm{M}$ $\mathrm{KH}_{2} \mathrm{PO}_{4}$ was added to the mixture and it was washed three times with $\mathrm{DCM}$, dried over a $\mathrm{Na}_{2} \mathrm{SO}_{4}$ and evaporated under $\mathrm{N}_{2}$. The resulting extracts were methylated $\left(\mathrm{BF}_{3}-\mathrm{MeOH}\right)$, and separated over aluminium oxide into a DCM ('apolar') and a DCM:MeOH (1:1)('polar') fraction. The polar fractions, containing the BHP periodic acid degradation products, were silylated with N,O-bis(trimethylsilyl)trifluoroacetamide (BSTFA) and pyridine $(1: 1 \mathrm{v} / \mathrm{v})$ at $60^{\circ} \mathrm{C}$ for $20 \mathrm{~min}$ and dissolved in ethyl acetate.

\subsubsection{GC, GC-MS, and GC-IRMS analysis}


Polar fractions were analysed by gas chromatography-mass spectrometry (GC-MS; Thermo Trace GC Ultra coupled to a Thermo Trace DSQ). The GC was equipped with a fused silica column ( $25 \mathrm{~m} \mathrm{x}$ $0.32 \mathrm{~mm}$ i.d., film thickness $0.1 \mu \mathrm{m}$ ) coated with CP Sil-5CB with helium as a carrier gas. Samples were injected on-column at $70{ }^{\circ} \mathrm{C}$, temperature was increased at $20{ }^{\circ} \mathrm{C} / \mathrm{min}$ to $130{ }^{\circ} \mathrm{C}$, raised further at $4{ }^{\circ} \mathrm{C} / \mathrm{min}$ to $320^{\circ} \mathrm{C}$, followed by an isothermal hold for $20 \mathrm{~min}$. Hopanoids were identified by comparison with known mass spectra.

The samples of the BRH peat profile were additionally analysed by GC-MS with a Selective Ion Monitoring (SIM) method specifically set-up to sensitively scan for the presence of the hopanoids identified in the biomass of Methylomirabilis spp. This SIM method exclusively scanned for the $\mathrm{m} / \mathrm{z} 191$, $205,189,203,217,279,293$, and 307 , as these were characteristic fragment ions of the designated compounds (as indicated in Fig. 2).

For analyses of the stable carbon isotope content of the generated hopanols, silylated polar fractions were analysed by GC coupled to isotope ratio mass spectrometry (GC-IRMS; Agilent 6890 coupled to a Thermo DeltaV IRMS) (in duplicate) as described previously (Schouten et al., 1998). Raw data were corrected for the (known) $\delta^{13} \mathrm{C}$ content of the (three) methyl groups added during silylation of the polar compounds.

\subsubsection{Extraction of intact BHPs}

Freeze dried biomass was extracted using a modified Bligh and Dyer technique as described by Schouten et al. (2008). In short, the samples were extracted by sonication in a solvent mixture containing phosphate buffer, $\mathrm{MeOH}$, and DCM (0.8:2:1, v:v:v). After sonication (10 min) DCM and phosphate buffer were added to reach a ratio of phosphate buffer:MeOH:DCM of 0.9:1:1 (v:v:v). After centrifugation the DCM layer was collected and the residue was re-extracted twice using the same procedure. The combined DCM layers were dried under a continuous nitrogen flow.

All lipid extracts were acetylated with acetic anhydride and pyridine $(0.5 \mathrm{~mL}, 1: 1 \mathrm{v} / \mathrm{v})$ for $1 \mathrm{~h}$ at $50^{\circ} \mathrm{C}$ and left at room temperature overnight, after which the solvent was removed under a continuous $\mathrm{N}_{2}$ flow. The acetylated extract was dissolved in methanol:propan-2-ol (3:2 v/v) and filtered over $0.2 \mu \mathrm{m}$ PTFE filters prior to HPLC-MS analysis.

\subsubsection{HPLC-MS analysis}

Reversed-phase HPLC analysis of the acetylated BHPs was carried out using a slightly modified method to that described previously (Cooke et al., 2008) using a Surveyor HPLC system (Thermo Finnigan, Hemel Hempstead, UK) equipped with a Phenomenex (Macclesfield, UK) Gemini $\mathrm{C}_{18} 5 \mu \mathrm{m}$ HPLC column (150 mm x $3 \mathrm{~mm}$ i.d.) and a Phenomenex Security Guard ${ }^{\mathrm{TM}}$ column of the same material. Separation over the column was obtained with a flow rate of $0.5 \mathrm{ml} / \mathrm{min}$ at $30{ }^{\circ} \mathrm{C}$ with a solvent gradient profile starting at $90 \% \mathrm{~A}$ and $10 \% \mathrm{~B}(0-3 \mathrm{~min})$, to $59 \% \mathrm{~A}, 1 \% \mathrm{~B}$ and $40 \% \mathrm{C}$ at $25 \mathrm{~min}$, then isocratic to 40 min, then returning to starting conditions over $5 \mathrm{~min}$ and stabilizing for $15 \mathrm{~min}$ (with $\mathrm{A}=\mathrm{MeOH}, \mathrm{B}=$ water, $\mathrm{C}=$ propan-2-ol; all HPLC-grade). For HPLC-MS, a Thermo Finnigan LCQ ion trap MS instrument equipped with an atmospheric pressure chemical ionization (APCI) source operated in positive ion mode was used. HPLC-MS was performed in data-dependent mode with two scan events: SCAN 1 over the whole spectrum (m/z 300-1300) and with SCAN 2, a data-dependent $\mathrm{MS}^{2}$ spectrum recorded for the most abundant ion from SCAN 1. Most intact BHPs were identified by comparison of the mass spectra to known BHP mass spectra (Talbot et al., 2003a, b). BHPs were quantified relative to the total amount of BHPs, assuming similar response factors for the various non-amine containing BHPs.

For the environmental samples, a customized method was additionally used to selectively detect the BHPs present in Methylomirabilis spp. enrichment cultures. This selective scanning method was set to specifically scan for MS ${ }^{2}$ spectra (SCAN 2) of ions in SCAN 1 of m/z 655, 669, 713, 727, 771, and 785, characteristic for BHP-tetrol (IIa), 3-methyl BHP-tetrol (IIb), BHP-pentol (IIIa), 3-methyl BHP-pentol (IIIb), BHP-hexol (IVa), and 3-methyl BHP-hexol (IVb), respectively. 


\section{RESULTS}

\subsection{Hopanoids in enrichment cultures of Methylomirabilis spp.}

Biomass of four enrichment cultures of the anaerobic methanotroph Methylomirabilis spp. were analysed for the presence of hopanoids by periodic acid treatment and by direct analysis with LC-MS. These cultures had been enriched from three different freshwater systems in the Netherlands, and had showed steady methane-oxidizing and nitrite-reducing activity for at least several months. Periodic acid treatment of biomass extracts converts relatively complex BHPs (II-IV) to more readily analysable terminal hopanols (Ia-If), and indeed revealed the presence of hopanoids in our extracts of enrichment cultures of Methylomirabilis spp.. A representative mass chromatogram of the polar fraction after periodic acid treatment of the extract of biomass of enrichment culture Ooij-2 is shown in Fig. 2. Three major hopanoids were identified by GC-MS as the TMS derivatives of $\mathrm{C}_{30}, \mathrm{C}_{31}$ and $\mathrm{C}_{32}$ regular hopanols (Ia, Ic, Ie) and as hopanols with an additional methyl group at the A-ring (Ib, Id, If). Two of the methylated hopanols ( $\mathrm{Ib}$ and I) co-eluted with the $\mathrm{C}_{31}$ and $\mathrm{C}_{32}$ regular hopanols Ic and Ie (Fig. 2). Based on their relative retention times, the methylated hopanoids were identified as 3-methyl hopanols, since 2-methyl hopanols would elute earlier, i.e. with retention times similar to their non-methyl counterparts (Summons and Jahnke, 1992). The profiles of hopanols obtained by periodic acid treatment of the extracts of enrichment cultures Ooij-1, WWTP and BRH were similar to that of Ooij-2, all showing the presence of $\mathrm{C}_{30}, \mathrm{C}_{31}$ and $\mathrm{C}_{32}$ hopanoids and their 3-methyl derivatives (Fig. 3). In BRH, the relative abundance of the $\mathrm{C}_{32}$ hopanol Ie was somewhat higher compared to the other enrichment cultures.

HPLC-MS analysis of BHPs in the biomass of the Methylomirabilis spp. enrichment cultures revealed the presence of bacteriohopanetetrol (BHT, IIa), bacteriohopanepentol (BHP-pentol, IIIa), bacteriohopanehexol (BHP-hexol, IVa), and the 3-methyl derivatives of all three BHPs as the major BHPs (IIb, IIIb, and IVb, respectively) (Fig. 4). BHT IIa is a commonly observed BHP and its characteristic fragmentation pattern has been described in detail (Talbot et al., 2003a). BHP-pentol IIIa and -hexol IVa are less common but fragment in a similar way (Fig. 4), losing one or two additional acetyl groups (acetylated hydroxyl-groups), supporting the interpretation of these BHPs as such (Talbot et al., 2003a). The mass spectra of the corresponding 3-methyl derivatives IIb, IIIb, and IVb are characterized by the fragment ion of $\mathrm{m} / \mathrm{z} 205$ instead of 191, and the series of fragments resulting from a characteristic neutral loss of 206 instead of $192 \mathrm{Da}$ (as a result from cleavage in ring-C between C-9 and 11 and C-8 and 14) (Talbot et al., 2003a), and a parent ion $\left(\left[\mathrm{M}+\mathrm{H}_{-} \mathrm{CH}_{3} \mathrm{COOH}\right]^{+}\right.$for non- $\mathrm{N}$-containing BHPs), whose $\mathrm{m} / \mathrm{z}$ value is 14 units higher than that of the non-methyl BHPs (Fig. 4). The identification of the location of the additional methyl group at the $\mathrm{C} 3$ position (rather than $\mathrm{C} 2$ ) is tentative and based on retention time: 2methyl BHPs would elute substantially earlier than the 3-methyl BHPs IIb, IIIb and IVb, which elute slightly later than the non-methyl BHPs IIa, IIIa, and IVa (Fig. 4). BHP-hexols IVa and IVb make up 50 to $80 \%$ of the total BHPs of each enrichment culture and 20 to $50 \%$ of all BHPs are methylated at the C3 position (Fig. 5). Overall, the distribution of BHPs in Ooij-1, Ooij-2 and WWTP are similar, whilst enrichment culture BRH contains a relatively large proportion of BHP-hexol IVa (Fig. 5). Overall these results match well with the recovered compounds identified after the periodic acid treatment, since $\mathrm{C}_{30}$, $\mathrm{C}_{31}$, and $\mathrm{C}_{32}$ regular hopanols and their 3-methyl derivatives (Ia-h) are the anticipated degradation products of hexa-, penta-, and tetrafunctionalised BHPs. Only in BRH there is a discrepancy, where the relative abundance of BHT IIa is markedly lower than the abundance of its anticipated product after periodic acid treatment, i.e. the $\mathrm{C}_{32}$ hopanol Ie (cf. Figs. 3 and 5). However, we did also identify two other commonly occurring tetrafunctionalised BHPs in this sample that were not detected in the other enrichment cultures, i.e. BHP-aminotriol IIc and BHT cyclitol ether IIf, which would also contribute to the $\mathrm{C}_{32}$ hopanol product Ie. The enrichment culture $\mathrm{BRH}$ is of all enrichment cultures the least enriched (about $70 \%$ for BRH versus $80 \%$ for the others), containing a larger side bacterial community than the other enrichment cultures. Moreover, the strain dominating this enrichment culture constitutes another species within the genus Methylomirabilis, whilst the other three are considered to contain the same species, $M$. oxyfera. 


\subsection{Stable carbon isotope labelling experiment}

The Ooij-1 enrichment culture of $M$. oxyfera was incubated with ${ }^{13} \mathrm{C}$-labelled $\mathrm{CH}_{4}$ and/or bicarbonate to identify the prime carbon source of the M. oxyfera hopanoids. Stable carbon isotope analyses cannot be carried out on the LC-amenable BHPs, so $\delta^{13} \mathrm{C}$ values were determined on the (GC-amenable) hopanol products after periodic acid degradation. Because of co-elution of the regular and 3-methyl hopanols (Fig. 2), isotopic signatures could not be distinguished for all individual hopanols. The isotope values reported are those of hopanol (Ia) and the integrated values of the coeleuting homohopanol (Ic) and 3-methyl hopanol (Ic), and bishomohopanol (Ie) and 3-methyl homohopanol (Id). The analyses showed that the incubations with ${ }^{13} \mathrm{C}$-enriched $\mathrm{CH}_{4}$ resulted in only little enrichment of hopanols $\left(\Delta \delta^{13} \mathrm{C}\right.$ of $6.4,1.8$ and $10.8 \%$, respectively; Fig. 6). However, when the enrichment culture was supplied with ${ }^{13} \mathrm{C}$-bicarbonate (and unlabelled $\mathrm{CH}_{4}$ ), considerably more incorporation of the ${ }^{13} \mathrm{C}$-label into hopanoids of $M$. oxyfera was observed $\left(\Delta \delta^{13} \mathrm{C}\right.$ of $40.2,8.6$ and $25.0 \%$, respectively; Fig. 6). In the absence of $\mathrm{CH}_{4}$, no incorporation from ${ }^{13} \mathrm{C}$-bicarbonate was observed (data not shown).

\subsection{Environmental detection of Methylomirabilis spp. BHPs}

We investigated a soil profile $(51$ to $102 \mathrm{~cm})$ from the Brunssummerheide peatland for the presence of the hopanoids found in Methylomirabilis spp. enrichment cultures. In this section of the soil profile a counter gradient of methane and nitrate was observed, coinciding with a peak in abundance of Methylomirabilis spp.-like bacteria as measured by quantitative polymerase chain reaction (qPCR) and an Methylomirabilis spp.-specific fatty acid (Kool et al., 2012; Zhu et al., 2012). All horizons of the soil profile contained $\mathrm{C}_{30}, \mathrm{C}_{31}$ and $\mathrm{C}_{32}$ regular hopanols (Ia, Ic, and Ie) after periodic acid treatment. Bishomohopanol Ie was most abundant; $\mathrm{C}_{30}$ and $\mathrm{C}_{31}$ regular hopanols (Ia and Ic) were present in small amounts, and elevated relative abundance of the $\mathrm{C}_{30}$ hopanol Ia was observed in the 80 to $100 \mathrm{~cm}$ soil horizons (Fig. 7). The presence of 3-methyl hopanols could not be identified with certainty with the full scan GC-MS analyses. However, when SIM (see methods) was applied, the presence of (low amounts of) 3-methyl derivatives of the $\mathrm{C}_{30}, \mathrm{C}_{31}$ and $\mathrm{C}_{32}$ hopanols ( $\mathrm{Ib}$, Id, If) was confirmed.

The LC-MS BHP analyses revealed the presence of several BHPs in the peat soil samples other than those present in Methylomirabilis spp. enrichment cultures. Particularly, BHP-aminotriol IIc was abundant throughout the profile, matching the high recovery of $\mathrm{C}_{32}$ hopanol Ie after periodic acid treatment (Fig. 7). The prominent presence of BHP-aminotriol interfered with the (conclusive) identification of BHP-pentol IIIa, as BHP-aminotriol IIc has a retention time close to BHP-pentol and a parent ion (protonated molecule) of $\mathrm{m} / \mathrm{z}$ of 714 , where BHP-pentol gives a characteristic major fragment of $\mathrm{m} / \mathrm{z} 713$ (parent ion minus the loss of one acetyl group) (e.g. Talbot et al., 2003a). Using a selective scanning method, the presence of BHP-pentol remained hard to verify as the specified $\mathrm{MS}^{2}$ spectra of $\mathrm{m} / \mathrm{z} 713$ primarily derived from an actual parent ion of $\mathrm{m} / \mathrm{z} 714$ (and additional fragment ions) of BHP-aminotriol. For the analyses of the LC-MS amenable BHPs, we further specifically focused on the detection of BHP-hexol IVa and its 3-methyl derivative (IVb), as these appear to be most characteristic for Methylomirabilis spp.. Data from the full scan (SCAN 1) suggested the possible presence of BHP-hexol IVa and 3-methyl BHP-hexol IVb by the detection of peaks in the $\mathrm{m} / \mathrm{z} 771$ and 785 mass chromatograms in several of the samples of the Brunssummerheide profile, namely all those between 70 and $95 \mathrm{~cm}$. Retention times of these compounds corresponded with their expected retention times. However, due to the low relative abundance no $\mathrm{MS}^{2}$ spectra could be obtained to verify their identity with the normal HPLC method. With a selective scanning method (see methods), however, we were able to acquire the essential $\mathrm{MS}^{2}$ spectra of these compounds in a few samples, which matched with the spectra obtained from the enrichment cultures. The presence of BHP-hexol IVa could be confirmed in the $80-85 \mathrm{~cm}$ and $85-90 \mathrm{~cm}$ horizons of the soil profile, which matches with the depth where the highest relative abundance of $\mathrm{C}_{30}$ hopanol Ia after periodic acid degradation was observed (Fig. 7). An $\mathrm{MS}^{2}$ spectrum, confirming the presence of the 3-methyl BHP-hexol $\mathrm{IVb}$ could only be obtained from one horizon $(85-90 \mathrm{~cm})$. 


\section{DISCUSSION}

\subsection{BHP composition of Methylomirabilis spp.}

Our data suggest that the methanotrophic bacterium Methylomirabilis sp. synthesizes distinct BHPs. Since Methylomirabilis spp. have not been obtained as pure cultures and were consequently grown in enrichment cultures, which contained $20-30 \%$ of other bacteria, it cannot be fully excluded that these other bacteria are producing the BHPs. However, this possibility is deemed rather unlikely since all other bacterial species represent only insignificant amounts of the total enrichment culture (Ettwig et al., 2010) and are unlikely to contribute a substantial part of the lipids. Furthermore, the labeling experiment revealed that the hopanoids showed the same labeling pattern as the Methylomirabilis spp.-specific fatty acids (cf. Rasigraf et al., 2014). Some less specific fatty acids (e.g. $C_{18: 0}$; Rasigraf et al., 2014) showed a completely different labeling pattern and these fatty acids are thought to be derived from the co-existing bacteria in the enrichment culture (Rasigraf et al., 2014).

The dominance of hexa- and pentafunctionalised BHPs and BHPs with an additional methyl group at the $\mathrm{C}_{3}$ position in Methylomirabilis spp. is highly unusual and characteristic. Tetrafunctionalised BHPs are by far the most common and abundant of all BHPs in both culture and environmental samples (Talbot et al., 2008). Also in anaerobic bacteria, the BHPs produced seem to be primarily tetrafunctionalised, mainly in the form of BHT (IIa) (Eickhoff et al., 2013; Fischer et al., 2005; Sinninghe Damsté et al., 2004), or with three hydroxyl-groups and an alternative group at the C-35 position such as an amine (IIc), cyclitol ether IIf), glucosamine (IIe), or glycoside (Blumenberg et al., 2006; Eickhoff et al., 2013; Hermans et al., 1991; Llopiz et al., 1992; Neunlist et al., 1985; Rashby et al., 2007). The only exceptions to our knowledge are the reported minor amounts of aminotetrol (IIIc) in some SRB of the genus Desulfovibrio (Blumenberg et al., 2006), and the $\mathrm{C}_{31}$ and $\mathrm{C}_{30}$ hopanols produced by periodic acid treatment from Geobacter sulfurreducens (Fischer et al., 2005) that suggest the presence of (small amounts of) penta- and hexafunctionalised BHPs as precursors, although the presence of these structure was not confirmed via LC/MS analysis of samples of the same organism (Eickhoff et al., 2013). Overall, the high abundance of penta- and hexafunctionalised BHPs found here in the anaerobic methanotroph Methylomirabilis sp. is exceptional as other methanotrophs that synthesize hexa- or pentafunctionalised BHPs in high abundance produce these as aminopentol (IVc) and aminotetrol (IIIc). We did observe some minor (tetrafunctionalized) amino BHPs in the enrichment culture BRH, but not in any of the other enrichment cultures. It is therefore likely that these amino BHPs are produced by the side-community in the enrichment cultures, while Methylomirabilis spp. only synthesizes non-amino-BHPs.

Known hexafunctionalised BHPs are the hexol (IVa), aminopentol (IVc) and its C3-methyl derivative (IVd), and hexol cyclitol ether: BHP-hexol and the hexol-cyclitol ether are only occasionally found in the environment (e.g. Cooke et al., 2008; Handley et al., 2010; Talbot and Farrimond, 2007; Berndmeyer et al., 2013; Talbot et al., 2014; Wagner et al., 2014). BHP-aminopentol IVc and the methylated derivative IVd is thus far associated with type I methanotrophs (Cvejic et al., 2000; Neunlist and Rohmer, 1985b; Talbot et al., 2001; van Winden et al., 2012) with one additional report of extremely low trace levels in one SRB (Blumenberg et al., 2012). Whilst aminopentol IVc is reported quite frequently in environmental studies (e.g. Talbot and Farrimond 2007; Coolen et al., 2008; Talbot et al., 2008; Zhu et al., 2010; van Winden et al., 2012; Wagner et al., 2014), the C3-methyl derivative IVd has only been reported, together with the non-methylated form, in a small number of settings including one lake sediment (Talbot and Farrimond, 2007), a geothermal silica sinter (Gibson et al., 2008) and the water column of the Black Sea (Blumenberg et al., 2007). Methylomirabilis spp. belong to the NC10 phylum, which together with A. acidoterrestris (Rezanka et al., 2011) (phylum: Firmicutes) comprise the only two known sources of hexafunctionalised BHPs outside the proteobacteria, and the only known source organisms for BHP-hexol IVa.

The pentafunctionalised BHP-pentol IIIa is not exclusive to Methylomirabilis spp.. Cyanobacteria have previously been reported to be able to produce this BHP (Bisseret et al., 1985;; Zhao et al., 1996), 
and it was observed in the thermophilic bacterium Alicyclobacillus acidoterrestris (Rezanka et al., 2011), but it may in specific environments still serve as an additional biomarker for Methylomirabilis spp.. Other pentafunctionalised BHPs are aminotetrol (IIIc) and composite BHPs with a more complex group other than $\mathrm{OH}$ or $\mathrm{NH}_{2}$ attached at the terminal position of the side chain. BHP-aminotetrol IIIc is considered characteristic for methanotrophs, although it is also found at low levels in certain (anaerobic) SRB (Blumenberg et al., 2006, 2009, 2012). Composite pentafunctionalised BHPs have been reported with a carbapseudopentose or cyclitol ether group at the C35 position (e.g. Talbot et al., 2008). The carbapseudopentose-form is rare and no source organism is known for it, although the tetrafunctionalised carbapseudopentose was identified in an enrichment culture of a cyanobacterium (Talbot et al., 2008). In the environment, the pentafunctionalised compounds have thus far only been detected in samples from Antarctica (Talbot et al., 2008). The pentafunctionalised BHP cyclitol ether is more common in the environment, and has been found in the nitrogen fixing Azotobacter vinelandii (Vilcheze et al., 1994), in an Acetobacter sp. (Hermann et al., 1996), in Frateuria aurantia (Joyeux et al., 2004), and in trace amounts in the cyanobacterium Chlorogloeopsis sp. LA (Talbot et al., 2003b). Methylomirabilis spp. constitutes one of the few organisms that are known to synthesize BHP-pentol IIIa, and forms an additional example of pentafunctionalised BHPs in methanotrophic organisms.

3-Methyl BHPs can, according to genetic analyses, only be produced by organisms with an aerobic metabolism (Welander and Summons, 2012). M. oxyfera employs an aerobic metabolism but produces the required oxygen itself internally, while it thrives in anoxic environments (Ettwig et al., 2010). Although the potential for $M$. oxyfera to synthesize 3-methyl-BHPs was already indicated by its genomic composition (Welander and Summons, 2012), the demonstrated presence of these hopanoids in this study of Methylomirabilis spp. enrichment cultures now directly shows that 3-methyl hopanoids can also be produced in anoxic settings. Most remarkable is the discovery of 3-methyl HP-hexol IVb, which to our knowledge has never been reported previously. This 3-methyl BHP-hexol provides a new biomarker for Methylomirabilis spp., and possibly other similar intra-aerobic methanotrophs.

\subsection{Biomarkers for Methylomirabilis spp. in the environment}

We propose that the distinct BHP composition of Methylomirabilis spp. may be used to identify the presence of this bacterium in the environment. Both BHP-hexol IVa and the 3-methyl-BHP-hexol IVb could be detected in the field samples from Brunssummerheide, where genomic and fatty acid analyses had previously verified the presence of Methylomirabilis spp. (Kool et al., 2012; Zhu et al., 2012). This demonstrates the potential for these unusual BHPs as diagnostic biomarker for Methylomirabilis spp. and possibly related species.

Methylomirabilis spp. also produces the less characteristic BHP-pentol but, unfortunately, the detection of this BHP in our environmental samples was inconclusive. Positive identification of BHPpentol in environmental samples where aminotriol is abundant is obscured by co-elution and the fact that the base peaks of these BHPS (i.e. the protonated molecular ion of BHP-aminotriol and the fragment ion formed by loss of one acetyl group for BHP-pentol) differ by only 1 mass unit. A possible solution to this may be to analyse the BHPs in their non-acetylated form, in which BHP-aminotriol and BHP-pentol will not show the overlapping $\mathrm{m} / \mathrm{z}$ values of their key characteristic (parent or fragment) ion of 714 and 713 (when acetylated). Nevertheless, using a similar method analysing acetylated BHPs, previous studies have been able to identify BHP-pentol in the environment, where co-occurrence of BHP-aminotriol apparently did not constrain the identification of BHP-pentol (Blumenberg et al., 2009b; Pancost et al., 2005; Sáenz et al., 2011). Though the main known source organisms for BHP-pentol, cyanobacteria (Zhao et al., 1996), live under oxic conditions, BHP-pentol has also been observed in oxygen-limited environments and may thus originate from Methylomirabilis spp. or related organisms. Pancost et al. (2005) reported (low quantities of) BHP-pentol in carbonate crusts in the Gulf of Mexico, Blumenberg et al. (2009b) reported BHP-pentol in Black Sea sediments (2009b), and Sáenz et al. (2011) reported its presence in the oxygen minimum zones (OMZs) of the Arabian Sea, the Peru margin, and the Cariaco basin below the photic zone. However, relating these compounds to anoxic or oxygen limiting conditions remains ambiguous, as 
the BHPs may not have been produced in situ but higher up in the water column under oxygenated conditions.

\subsection{Stable carbon isotope composition of $M$. oxyfera BHPs and implications for the geological record}

In addition to the structural composition of BHPs and lipids in general, their carbon stable isotope content can provide a useful tool to identify the occurrence of methanotrophs (e.g. Blumenberg et al., 2004; Coolen et al., 2008; Jahnke et al., 1999; Summons et al., 1994). Especially for the less diagnostic diagenetic products of BHPs, stable carbon isotope analyses serve as complementary tool to confirm a methanotrophic origin of these compounds. Biogenic methane is typically substantially depleted in ${ }^{13} \mathrm{C}$, and this distinct low $\delta^{13} \mathrm{C}$ signature of $\mathrm{CH}_{4}$ is generally reflected in the biomass and lipids of those organisms that consume $\mathrm{CH}_{4}$. However, a wide range in depletion of the $\mathrm{C}$ isotope composition of BHPs and geohopanoids related to methanotrophy has been reported, from $\delta^{13} \mathrm{C}$ values as low as $-90 \%$ to as high as -30\%o (e.g. Birgel et al., 2006, 2011; Burhan et al., 2002; Coolen et al., 2008; Elvert et al., 2000; Hinrichs, 2001; Talbot et al., 2014; Thiel et al., 2003; van Winden et al., 2010). Our carbon isotope labelling experiments showed that $M$. oxyfera incorporated carbon from ${ }^{13} \mathrm{C}$-labeled bicarbonate into its hopanoids, while it incorporated little ${ }^{13} \mathrm{C}$ from ${ }^{13} \mathrm{C}$-labeled $\mathrm{CH}_{4}$ (Fig. 6). These results are in good agreement with earlier results showing that bicarbonate/ $\mathrm{CO}_{2}$ is the main actual carbon source for $M$. oxyfera cell material and fatty acids (Rasigraf et al., 2014). Autotrophy has recently also been shown to be more common than previously thought in other methanotrophs. Although no isotope experiments were conducted, the verrucomicrobial methanotroph Methylacidiphilum fumariolicum SolV was shown to oxidize carbon autotrophically (Khadem et al., 2011), and to also produce hopanoids, primarily aminotriol IIc (van Winden et al., 2012).

Overall, this implies that hopanoids that originate from methanotrophic organisms do not necessarily show a distinct depleted ${ }^{13} \mathrm{C}$ isotopic signature, which is commonly anticipated with methanotrophy. Such 'less-depleted' signals were for example reported in a Sphagnum peat system where hopenes and tetrafunctionalyzed hopanoids, interpreted as part of the predominant methanotroph lipids, displayed a carbon isotope content of $-31 \%$ to $-38 \%$ (van Winden et al., 2010). This may have implications for interpreting the sedimentary record as the observation of non-depleted hopanoids in ancient sediment would not necessarily rule out past methanotroph activity, as hopanoids can also be synthesized by autotrophic methanotrophs that assimilate carbon from $\mathrm{CO}_{2}$ instead of $\mathrm{CH}_{4}$, which thereby do not convey the distinct depleted carbon isotopic signature from $\mathrm{CH}_{4}$. However, in such settings DIC is typically also depleted due to production of $\mathrm{CO}_{2}$ from isotopically depleted organic matter or methane and, consequently, hopanoids produced by autotrophic methanotrophs may still have a relatively depleted isotope signature in these environment.

\section{CONCLUSIONS}

We investigated the BHP composition of the intra-aerobic methanotroph M. oxyfera. Our main findings are that M. oxyfera synthesizes characteristic BHPs, including 3-methyl BHPs, which provides the first report of the potential production of 3-methyl hopanoids in anoxic environments. Further, based on carbon isotope labelling experiments, we showed that methanotroph-derived hopanoids were produced from DIC and not from methane. Hopanoids produced by Methylomirabilis spp. do, therefore, not necessarily exhibit a strongly depleted carbon isotopic signature, which is commonly anticipated for methanotrophs. This may have implications for the interpretation of the presence of hopanoids and their isotopic signature in the paleorecord.

\section{Acknowledgements}

We would like to thank Baoli Zhu for providing the Brunssummerheide samples and Olivia Rasigraf for providing samples from the labelling experiment, and Frances Sidgwick for her assistance with the analyses of the intact BHPs. We acknowledge the three referees for their helpful comments. D.K. and 
K.F.E. were supported by the Darwin Center for Biogeosciences (projects 142.16 .3071 and 142.16.3072) through grants to J.S.S.D. and M.S.M. Jetten, respectively. This project was also partially funded by a Starting Grant (No. 258734) awarded to HMT for project AMOPROX from the European Research Council.

\section{References}

Berndmeyer, C., Thiel, V., Schmale, O. and Blumenberg, M. (2013) Biomarkers for aerobic methanotrophy in the water column of the stratified Gotland Deep (Baltic Sea). Org. Geochem. 55, 103-111.

Birgel, D., Feng, D., Roberts, H.H. and Peckmann, J. (2011) Changing redox conditions at cold seeps as revealed by authigenic carbonates from Alaminos Canyon, northern Gulf of Mexico. Chem. Geol. 285, 82-96.

Birgel, D., Thiel, V., Hinrichs, K.-U., Elvert, M., Campbell, K.A., Reitner, J., Farmer, J.D. and Peckmann, J. (2006) Lipid biomarker patterns of methane-seep microbialites from the Mesozoic convergent margin of California. Org. Geochem. 37, 1289-1302.

Bisseret, P., Zundel, M. and Rohmer, M. (1985) Prokaryotic triterpenoids: 2. $2 \beta$-methylhopanoids from Methylobacterium organophilum and Nostoc muscorum, a new series of prokaryotic triterpenoids. Eur. J. Biochem.150, 29-34.

Blumenberg, M., Seifert, R., Reitner, J., Pape, T. and Michaelis, W. (2004) Membrane lipid patterns typify distinct anaerobic methanotrophic consortia. Proc. Natl. Acad. Sci. U.S.A. 101, 11111-11116.

Blumenberg, M., Krüger, M., Nauhaus, K., Talbot, H.M., Oppermann, B.I., Seifert, R., Pape, T. and Michaelis, W. (2006) Biosynthesis of hopanoids by sulfate-reducing bacteria (genus Desulfovibrio). Environ. Microbiol. 8, 1220-1227.

Blumenberg M., Seifert R. and Michaelis W. (2007) Aerobic methanotrophy in the oxic-anoxic transition zone of the Black Sea water column. Org. Geochem. 38, 84-91.

Blumenberg, M., Oppermann, B.I., Guyoneaud, R. and Michaelis, W. (2009a) Hopanoid production by Desulfovibrio bastinii isolated from oilfield formation water. FEMS Microbiol. Lett. 293, 73-78.

Blumenberg, M., Seifert, R., Kasten, S., Bahlmann, E. and Michaelis, W. (2009b) Euphotic zone bacterioplankton sources major sedimentary bacteriohopanepolyols in the Holocene Black Sea. Geochim. Cosmochim. Acta 73, 750-766.

Blumenberg, M., Hoppert, M., Krueger, M., Dreier, A. and Thiel, V. (2012) Novel findings on hopanoid occurrences among sulfate reducing bacteria: Is there a direct link to nitrogen fixation? Org. Geochem. 49, 1-5.

Bringer, S., Härtner, T., Poralla, K. and Sahm, H. (1985) Influence of ethanol on the hoponoid content and the fatty acid pattern in batch and continuous cultures of Zymomonas mobilis. Arch. Microbiol. 140, 312-316.

Brocks, J.J., Love, G.D., Summons, R.E., Knoll, A.H., Logan, G.A. and Bowden, S.A. (2005) Biomarker evidence for green and purple sulphur bacteria in a stratified Palaeoproterozoic sea. Nature 437, 866870.

Burhan, R.Y.P., Trendel, J.M., Adam, P., Wehrung, P., Albrecht, P. and Nissenbaum, A. (2002) Fossil bacterial ecosystem at methane seeps: Origin of organic matter from Be'eri sulfur deposit, Israel. Geochim. Cosmochim. Acta 66, 4085-4101.

Cooke, M.P., Talbot, H.M. and Farrimond, P. (2008) Bacterial populations recorded in bacteriohopanepolyol distributions in soils from Northern England. Org. Geochem. 39, 1347-1358.

Coolen, M.J.L., Talbot, H.M., Abbas, B.A., Ward, C., Schouten, S., Volkman, J.K. and Sinninghe Damsté, J.S. (2008) Sources for sedimentary bacteriohopanepolyols as revealed by $16 \mathrm{~S}$ rDNA stratigraphy. Environ. Microbiol. 10, 1783-1803. 
Cvejic, J.H., Bodrossy, L., Kovacs, K.L. and Rohmer, M. (2000) Bacterial triterpenoids of the hopane series from the methanotrophic bacteria Methylocaldum spp.: phylogenetic implications and first evidence for an unsaturated aminobacteriopanepolyol. FEMS Microbiol. Lett. 182, 361-365.

Eickhoff, M., Birgel, D., Talbot, H.M., Peckmann, J. and Kappler, A. (2013) Bacteriohopanoid inventory of Geobacter sulfurreducens and Geobacter metallireducens. Org. Geochem. 58, 107-114.

Elvert, M., Suess, E., Greinert, J. and Whiticar, M.J. (2000) Archaea mediating anaerobic methane oxidation in deep-sea sediments at cold seeps of the eastern Aleutian subduction zone. Org. Geochem. 31, 1175-1187.

Ettwig, K.F., Butler, M.K., Le Paslier, D., Pelletier, E., Mangenot, S., Kuypers, M.M.M., Schreiber, F., Dutilh, B.E., Zedelius, J., Beer, D.d., Gloerich, J., Wessels, H.J.C.T., Alen, T.v., Luesken, F., Wu, M.L., Van De Pas-Schoonen, K.T., Op den Camp, H.J.M., Janssen-Megens, E.M., Francoijs, K.J., Stunnenberg, H., Weissenbach, J., Jetten, M.S.M. and Strous, M. (2010) Nitrate-driven anaerobic methane oxidation by oxygenic bacteria. Nature 464, 543-548.

Ettwig, K.F., van Alen, T., van de Pas-Schoonen, K.T., Jetten, M.S.M. and Strous, M. (2009) Enrichment and molecular detection of denitrifying methanotrophic bacteria of the NC10 phylum. Appl. Environ. Microbiol. 75, 3656-3662.

Fischer, W.W., Summons, R.E. and Pearson, A. (2005) Targeted genomic detection of biosynthetic pathways: anaerobic production of hopanoid biomarkers by a common sedimentary microbe. Geobiology 3, 33-40.

Gibson R.A., Kaur, P., Pancost, R. D., Mountain, B. and Talbot, H. M. (2008) Bacteriohopanepolyol signatures of cyanobacterial and methanotrophic bacterial populations recorded in a geothermal vent sinter. Org. Geochem. 39, 1020-1023.

Handley, L., Talbot, H.M., Cooke, M.P., Anderson, K.E. and Wagner, T. (2010) Bacteriohopanepolyols as tracers for continental and marine organic matter supply and phases of enhanced nitrogen cycling on the late Quaternary Congo deep sea fan. Org. Geochem. 41, 910-914.

Härtner, T., Straub, K.L. and Kannenberg, E. (2005) Occurrence of hopanoid lipids in anaerobic Geobacter species. FEMS Microbiol. Lett. 243, 59-64.

Herrmann D., Bisseret P., Connan J. and Rohmer M. (1996) A non-extractable triterpenoid of the hopanoid series in Acetobacter xylinum. FEMS Microbiol. Lett. 135, 323-326.

Hermans, M.A.F., Neuss, B. and Sahm, H. (1991) Content and composition of hopanois in Zymomonas mobilis under various growth conditions. J. Bacteriol. 173, 5592-5595.

Hinrichs, K.-U. (2001) A molecular recorder of methane hydrate destabilization. Geochemistry, Geophysics, Geosystems 2, 1029.

Jahnke, L.L., Summons, R.E., Hope, J.M. and des Marais, D.J. (1999) Carbon isotopic fractionation in lipids from methanotrophic bacteria II: The effects of physiology and environmental parameters on the biosynthesis and isotopic signatures of biomarkers. Geochim. Cosmochim. Acta 63, 79-93.

Joyeux, C., Fouchard, S., Llopiz, P. and Neunlist, S. (2004) Influence of the temperature and the growth phase on the hopanoids and fatty acids content of Frateuria aurantia (DSMZ 6220). FEMS Microbiol. Ecol. 47, 371-379.

Khadem, A.F., Pol, A., Wieczorek, A., Mohammadi, S.S., Francoijs, K.J., Stunnenberg, H.G., Jetten, M.S.M. and Op den Camp, H.J.M. (2011) Autotrophic methanotrophy in verrucomicrobia: Methylacidiphilum fumariolicum solv uses the Calvin-Benson-Bassham cycle for carbon dioxide fixation. J. Bacteriol. 193, 4438-4446.

Kool, D.M., Zhu, B., Rijpstra, W.I.C., Jetten, M.S.M., Ettwig, K.F. and Sinninghe Damsté, J.S. (2012) Rare branched fatty acids typify the lipid composition of the intra-aerobic methane oxidizer Methylomirabilis oxyfera. Appl. Environ. Microbiol. 78, 8650-8656.

Llopiz, P., Neunlist, S. and Rohmer, M. (1992) Prokaryotic triterpenoids - O-alpha-D-glucuronopyranosyl bacteriohopanetetrol, a novel hopanoid from the bacterium Rhodospirillum rubrum. Biochem. J. 287, 159-161.

Luesken, F.A., van Alen, T.A., van der Biezen, E., Frijters, C., Toonen, G., Kampman, C., Hendrickx, T.L.G., Zeeman, G., Temmink, H., Strous, M., Op den Camp, H.J.M. and Jetten, M.S.M. (2011) 
Diversity and enrichment of nitrite-dependent anaerobic methane oxidizing bacteria from wastewater sludge. Appl. Microbiol. Biotechnol. 92, 845-854.

Neunlist, S., Holst, O. and Rohmer, M. (1985) Prokaryotic triterpenoids - The hopanoids of the purple non-sulfur bacterium Rhodomicrobium vanniellii - an aminotriol and its aminoacyl derivatives, Ntryptophanyl and N-ornithinyl aminotriol. Eur. J. Biochem. 147, 561-568.

Neunlist, S. and Rohmer, M. (1985a) A novel hopanoid, 30-(5'-adenosyl)hopane, from the purple nonsulfur bacterium Rhodopseudomonas acidophila, with possible DNA interactions. Biochem. J. 228, 769-771.

Neunlist, S. and Rohmer, M. (1985b) Novel hopanoids from the methylotrophic bacteria Methylococcus capsulatus and Methylomonas methanica - (22S)-35-aminobacteriohopane-30,31,32,33,34-pentol and (22S)-35-amino-3-beta-methylbacteriohopane-30,31,32,33,34-pentol. Biochem. J. 231, 635-639.

Ourisson, G. and Albrecht, P. (1992) Hopanoids 1. Geohopanoids - The most abundant natural-products on earth. Acc. Chem. Res. 25, 398-402.

Ourisson, G., Albrecht, P. and Rohmer, M. (1979) Hopanoids - Palaeochemistry and biochemistry of a group of natural-products. Pure Appl. Chem. 51, 709-729.

Pancost, R.D., Zhang, C.L.L., Tavacoli, J., Talbot, H.M., Farrimond, P., Schouten, S., Sinninghe Damsté, J.S. and Sassen, R. (2005) Lipid biomarkers preserved in hydrate-associated authigenic carbonate rocks of the Gulf of Mexico. Palaeogeogr. Palaeoclimatol. Palaeoecol. 227, 48-66.

Rashby, S.E., Sessions, A.L., Summons, R.E. and Newman, D.K. (2007) Biosynthesis of 2methylbacteriohopanepolyols by an anoxygenic phototroph. Proc. Natl. Acad. Sci. U.S.A. 104, 15099-15104.

Rasigraf, O., Kool, D.M., Jetten M.S.M., Sinninghe Damsté, J.S. and Ettwig, K.F. (2014) Autotrophic carbon dioxide fixation via the Calvin-Benson-Bassham cycle by the denitrifying methanotroph Methylomirabilis oxyfera. Appl. Environm. Microbiol., doi: 10.1128/AEM.04199-13.

Rezanka, T., Siristova, L., Melzoch, K. and Sigler, K. (2011) N-acylated bacteriohopanehexolmannosamides from the thermophilic bacterium Alicyclobacillus acidoterrestris. Lipids 46, 249-261.

Ricci, J.N., Coleman, M.L., Welander, P.V., Sessions, A.L., Summons, R.E., Spear, J.R. and Newman, D.K. (2014) Diverse capacity for 2-methylhopanoid production correlates with a specific ecological niche. ISME Journal, doi:10.1038/ismej.2013.191.

Rohmer, M., and Ourisson, G. (1976) Structure of bacteriohopanetetrols from Acetobacter xylinum. Tet. Lett. 3633-3636.

Rohmer, M., Bouvier-Nave, P. and Ourisson, G. (1984) Distribution of hopanoid triterpenes in prokaryotes. J. Gen. Microbiol. 130, 1137-1150.

Sáenz, J.P., Wakeham, S.G., Eglinton, T.I. and Summons, R.E. (2011) New constraints on the provenance of hopanoids in the marine geologic record: Bacteriohopanepolyols in marine suboxic and anoxic environments. Org. Geochem. 42, 1351-1362.

Schouten, S., Breteler, W., Blokker, P., Schogt, N., Rijpstra, W.I.C., Grice, K., Baas, M. and Sinninghe Damsté, J.S. (1998) Biosynthetic effects on the stable carbon isotopic compositions of algal lipids: Implications for deciphering the carbon isotopic biomarker record. Geochim. Cosmochim. Acta 62, 1397-1406.

Schouten, S., Hopmans, E.C., Baas, M., Boumann, H., Standfest, S., Koenneke, M., Stahl, D.A. and Sinninghe Damsté, J.S. (2008) Intact membrane lipids of "Candidatus Nitrosopumilus maritimus," a cultivated representative of the cosmopolitan mesophilic group I crenarchaeota. Appl. Environ. Microbiol. 74, 2433-2440.

Sinninghe Damsté, J.S., Rijpstra, W.I.C., Schouten, S., Fuerst, J.A., Jetten, M.S.M. and Strous, M. (2004) The occurrence of hopanoids in planctomycetes: implications for the sedimentary biomarker record. Org. Geochem. 35, 561-566.

Summons, R.E. and Jahnke, L.L. (1992) Hopenes and hopanes methylated in ring-A: correlation of the hopanoids of extant methylotrophic bacteria with their fossil analogues. In Biological markers in Sediments and Petroleum (Eds. J.M. Moldowan, P. Albrecht, R.P. Philp). Prentice Hall, NJ, pp. 182200. 
Summons, R.E., Jahnke, L.L., Hope, J.M. and Logan, G.A. (1999) 2-Methylhopanoids as biomarkers for cyanobacterial oxygenic photosynthesis. Nature 400, 554-557.

Summons, R.E., Jahnke, L.L. and Roksandic, Z. (1994) Carbon isotopic fractionation in lipids from methanotrophic bacteria: Relevance for interpretation of the geochemical record of biomarkers. Geochim. Cosmochim. Acta 58, 2853-2863.

Talbot, H.M. and Farrimond, P. (2007) Bacterial populations recorded in diverse sedimentary biohopanoid distributions. Org. Geochem. 38, 1212-1225.

Talbot, H.M., Watson, D.F., Murrell, J.C., Carter, J.F. and Farrimond, P. (2001) Analysis of intact bacteriohopanepolyols from methanotrophic bacteria by reversed-phase high-performance liquid chromatography-atmospheric pressure chemical ionisation mass spectrometry. J. Chromatogr. A 921, 175-185.

Talbot, H.M., Squier, A.H., Keely, B.J. and Farrimond, P. (2003a) Atmospheric pressure chemical ionisation reversed-phase liquid chromatography/ion trap mass spectrometry of intact bacteriohopanepolyols. Rapid Commun. Mass Spectrom. 17, 728-737.

Talbot, H.M., Summons, R., Jahnke, L. and Farrimond, P. (2003b) Characteristic fragmentation of bacteriohopanepolyols during atmospheric pressure chemical ionisation liquid chromatography/ion trap mass spectrometry. Rapid Commun. Mass Spectrom. 17, 2788-2796.

Talbot, H.M., Summons, R.E., Jahnke, L.L., Cockell, C.S., Rohmer, M. and Farrimond, P. (2008) Cyanobacterial bacteriohopanepolyol signatures from cultures and natural environmental settings. Org. Geochem. 39, 232-263.

Talbot, H.M., Handley, L., Spencer-Jones, C., Bienvenu, D.J., Schefuß E., Mann, P., Poulson, J., Spencer, R., Wagner, T. (2014) Variability in aerobic methane oxidation over the past 1.2 Myrs recorded in microbial biomarker signatures from Congo fan sediments. Geochim. Cosmochim. Acta doi:10.1016/j.gca.2014.02.035

Thiel, V., Blumenberg, M., Pape, T., Seifert, R. and Michaelis, W. (2003) Unexpected occurrence of hopanoids at gas seeps in the Black Sea. Org. Geochem. 34, 81-87.

van Winden, J.F., Kip, N., Reichart, G.J., Jetten, M.S.M., Op den Camp, H.J.M. and Sinninghe Damsté, J.S. (2010) Lipids of symbiotic methane-oxidizing bacteria in peat moss studied using stable carbon isotopic labelling. Org. Geochem. 41, 1040-1044.

van Winden, J.F., Talbot, H.M., Kip, N., Reichart, G.-J., Pol, A., McNamara, N.P., Jetten, M.S.M., Op den Camp, H.J.M. and Sinninghe Damsté, J.S. (2012) Bacteriohopanepolyol signatures as markers for methanotrophic bacteria in peat moss. Geochim. Cosmochim. Acta 77, 52-61.

Vilcheze, C., Llopiz, P., Neunlist, S., Poralla, K. and Rohmer, M. (1994) Prokaryotic triterpenoids - new hopanoids from the nitrogen-fixing bacteria Azotobacter vinelandii, Beijerinckia indica and Beijerinckia mobilis. Microbiol.(UK) 140, 2749-2753.

Wagner, T., Kallweit, W., Talbot, H.M., Mollenhauer, G., Boom, A. and Zabel, M. (2014) Microbial biomarkers support organic carbon transport from methane-rich Amazon wetlands to the shelf and deep sea fan during recent and glacial climate conditions. Org. Geochem. 67, 85-98.

Welander, P.V., Coleman, M.L., Sessions, A.L., Summons, R.E. and Newman, D.K. (2010) Identification of a methylase required for 2-methylhopanoid production and implications for the interpretation of sedimentary hopanes. Proc. Natl. Acad. Sci. U.S.A. 107, 8537-8542.

Welander, P.V. and Summons, R.E. (2012) Discovery, taxonomic distribution, and phenotypic characterization of a gene required for 3-methylhopanoid production. Proc. Natl. Acad. Sci. U.S.A. 109, 12905-12910.

Zhao, N., Berova, N., Nakanishi, K., Rohmer, M., Mougenot, P. and Jurgens, U.J. (1996) Structures of two bacteriohopanoids with acyclic pentol side-chains from the cyanobacterium Nostoc PCC 6720. Tetrahedron 52, 2777-2788.

Zhu, B., van Dijk, G., Fritz, C., Smolders, A.J., Pol, A., Jetten, M.S.M. and Ettwig, K.F. (2012) Anaerobic oxidization of methane in a minerotrophic peatland: Enrichment of nitrite-dependent methaneoxidizing bacteria. Appl. Environ. Microbiol. 78, 8657-8665. 
Zhu, C., Talbot, H.M., Wagner, T., Pan, J.M. and Pancost, R.D. (2010) Intense aerobic methane oxidation in the Yangtze Estuary: A record from 35-aminobacteriohopanepolyols in surface sediments. Org. Geochem. 41, 1056-1059.

Zundel, M. and Rohmer, M. (1985a) Prokaryotic triterpenoids 1. 3-beta-methylhopanoids from Acetobacter species and Methylococcus capsulatus. Eur. J. Biochem. 150, 23-27.

Zundel, M. and Rohmer, M. (1985b) Prokaryotic triterpenoids 3. The biosynthesis of 2-betamethylhopanoids and 3-beta-methylhopanoids of Methylobacterium organophilum and Acetobacter pasteurianus spp. pasteurianus. Eur. J. Biochem. 150, 35-39. 
<smiles></smiles>

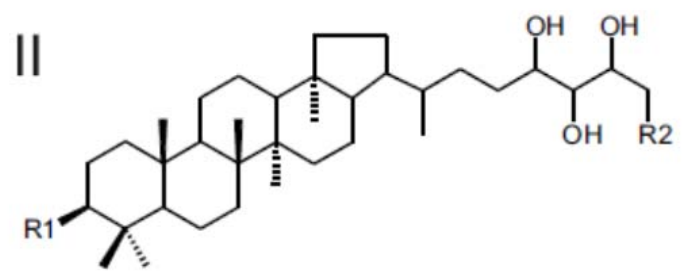

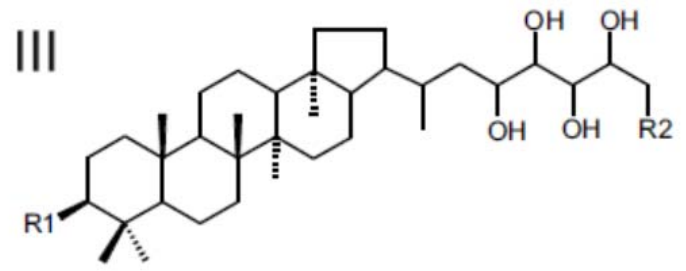

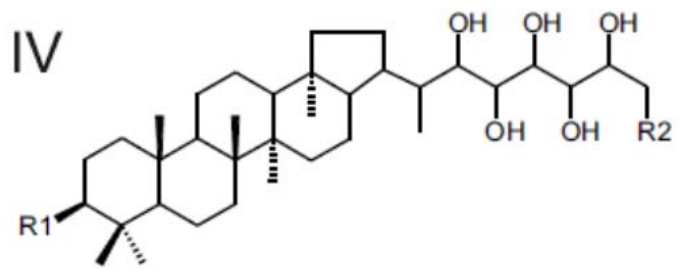

la. $\mathrm{C} 30$ hopanol; $\mathrm{R} 1=\mathrm{H}, \mathrm{R} 2=\mathrm{CH}_{2} \mathrm{OH}$

lb. 3-methyl-C31 hopanol; R1 $=\mathrm{CH}_{3}, \mathrm{R} 2=\mathrm{CH}_{2} \mathrm{OH}$

Ic. $\mathrm{C} 31$ hopanol; R1 $=\mathrm{H}, \mathrm{R} 2=\mathrm{C}_{2} \mathrm{H}_{4} \mathrm{OH}$

Id. 3-methyl- $\mathrm{C} 32$ hopanol; R1 $=\mathrm{CH}_{3}, \mathrm{R} 2=\mathrm{C}_{2} \mathrm{H}_{4} \mathrm{OH}$

le. $\mathrm{C} 32$ hopanol; $\mathrm{R} 1=\mathrm{H}, \mathrm{R} 2=\mathrm{C}_{3} \mathrm{H}_{6} \mathrm{OH}$

If. 3-methyl- $\mathrm{C} 33$ hopanol; $\mathrm{R} 1=\mathrm{CH}_{3}, \mathrm{R} 2=\mathrm{C}_{3} \mathrm{H}_{6} \mathrm{OH}$

Ila. BHTetrol (BHT); R1 $=\mathrm{H}, \mathrm{R} 2=\mathrm{OH}$

Ilb. 3-methyl-BHT; R1 $=\mathrm{CH}_{3}, \mathrm{R} 2=\mathrm{OH}$

Ilc. $B H P$ amino-triol; $\mathrm{R} 1=\mathrm{H}, \mathrm{R} 2=\mathrm{NH}_{2}$

Ild. 3-methyl-BHP amino-triol; R1 $=\mathrm{CH}_{3}, \mathrm{R} 2=\mathrm{NH}_{2}$ Ile. BHT glucosamine; R1 = H, R2 = "2) IIf. BHT cyclitol ether; R1 = H, R2 =

IIla. BHP pentol; R1 $=\mathrm{H}, \mathrm{R} 2=\mathrm{OH}$

IIllb. 3-methyl-BHP pentol; R1 $=\mathrm{CH}_{3}, \mathrm{R} 2=\mathrm{OH}$

IIlc. BHP amino-tetrol; R1 $=\mathrm{H}, \mathrm{R} 2=\mathrm{NH}_{2}$

IIId. 3-methyl-BHP amino-tetrol; R1 $=\mathrm{CH}_{3}, \mathrm{R} 2=\mathrm{NH}_{2}$

IVa. BHP hexol; R1 = H, R2 = OH

IVb. 3-methyl-BHP hexol; R1 $=\mathrm{CH}_{3}, \mathrm{R} 2=\mathrm{OH}$

IVc. BHP amino-pentol; $\mathrm{R} 1=\mathrm{H}, \mathrm{R} 2=\mathrm{NH}_{2}$

IVd. 3-methyl-BHP amino-pentol; R1 $=\mathrm{CH}_{3}, \mathrm{R} 2=\mathrm{NH}_{2}$

Fig. 1. Structures of various hopanoids, including tetra-, penta-, and hexafunctionalized bacteriohopanepolyols. 


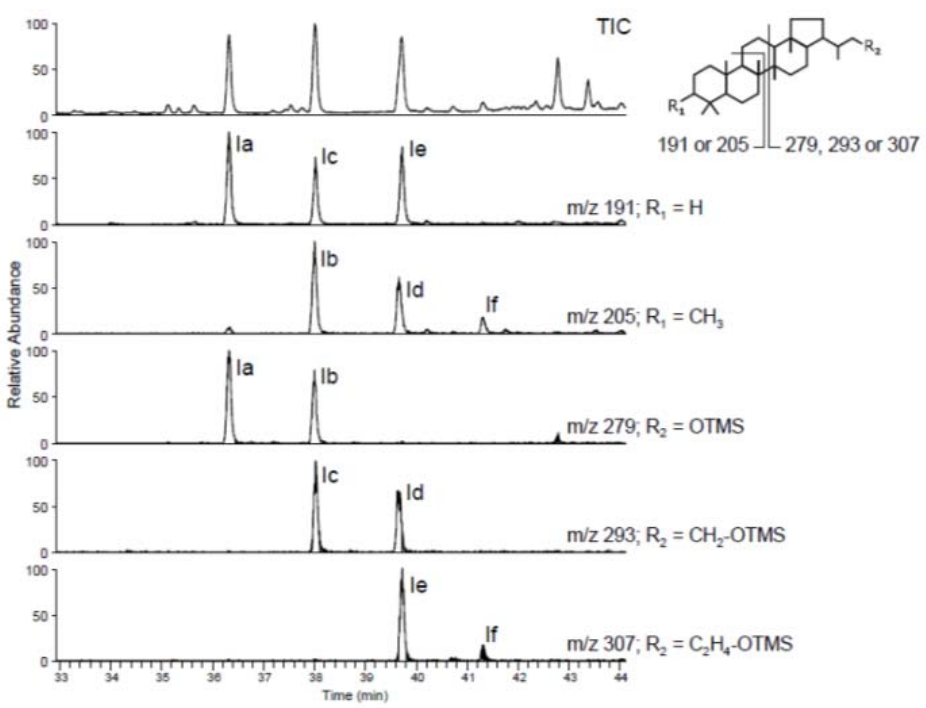

Fig. 2. Partial TIC and mass chromatograms (GC-MS) of the polar fraction after periodic acid treatment of the extract of M. oxyfera (enrichment culture WWTP). Characteristic fragments of $\mathrm{m} / \mathrm{z} 191$ and 205 are indicative of the hopanoids without and with additional methylation at the A-ring, respectively. Fragments of $m / z$ 279, 293, and 307 identify the length of the (TMS-derivatized) side chains. Numbers refer to structures depicted in Fig. 1.

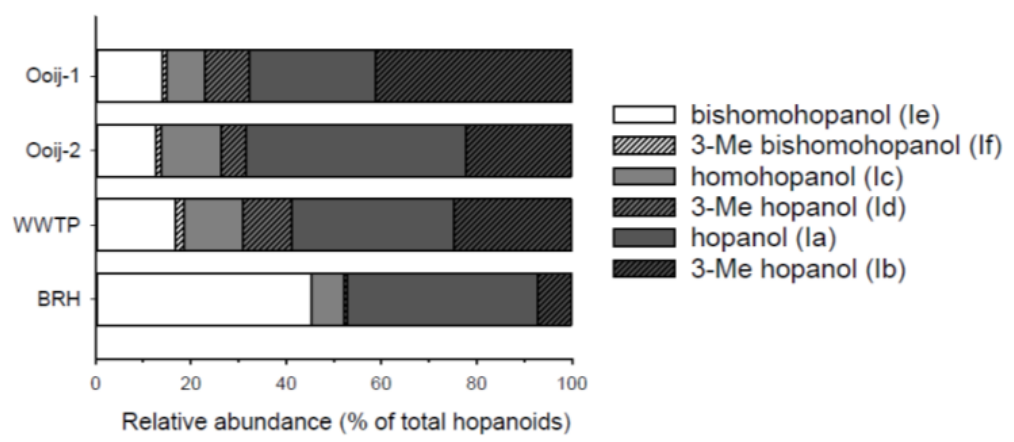

Fig. 3. Relative abundance of the $\mathrm{C}_{30}, \mathrm{C}_{31}, \mathrm{C}_{32}$ regular hopanols Ia, Ic, and Ie, and their 3-methyl derivatives $\mathrm{Ib}$, Id, and If (all analysed as TMS derivatives) in the product mixtures of periodic acid degradation of the four studied Methylomirabilis spp. enrichment cultures. Numbers refer to structures depicted in Fig. 1. 

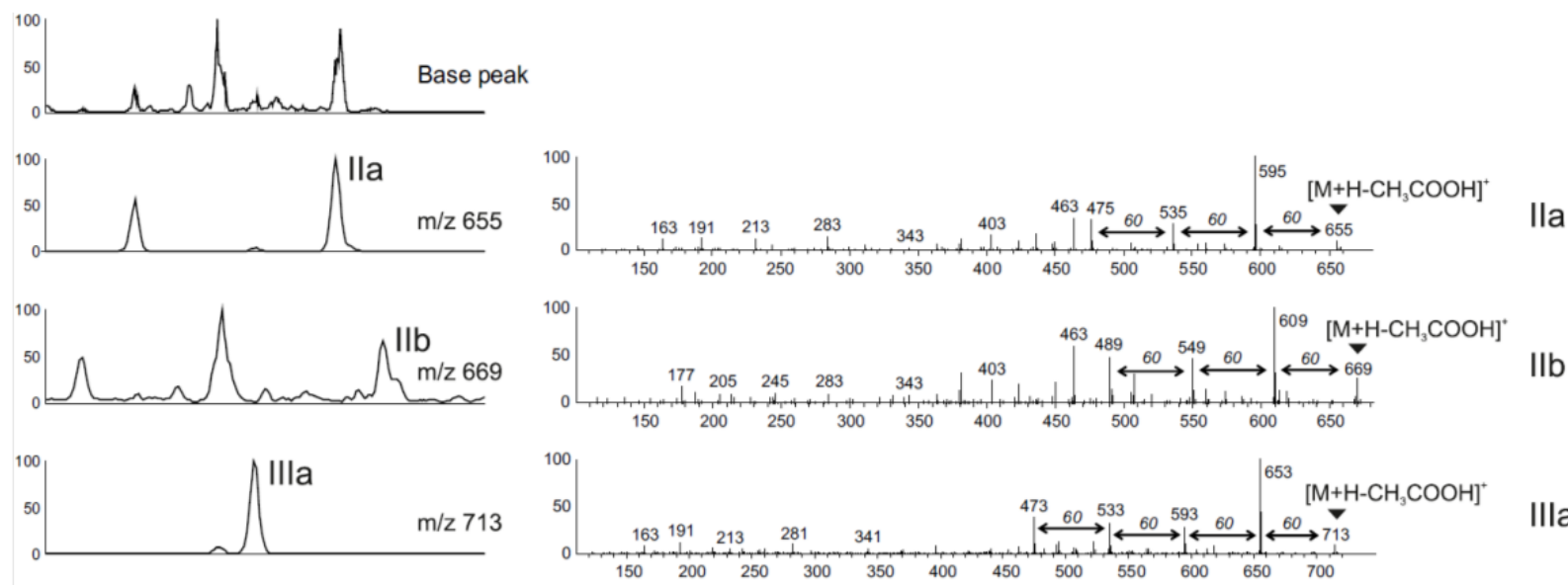

IIla
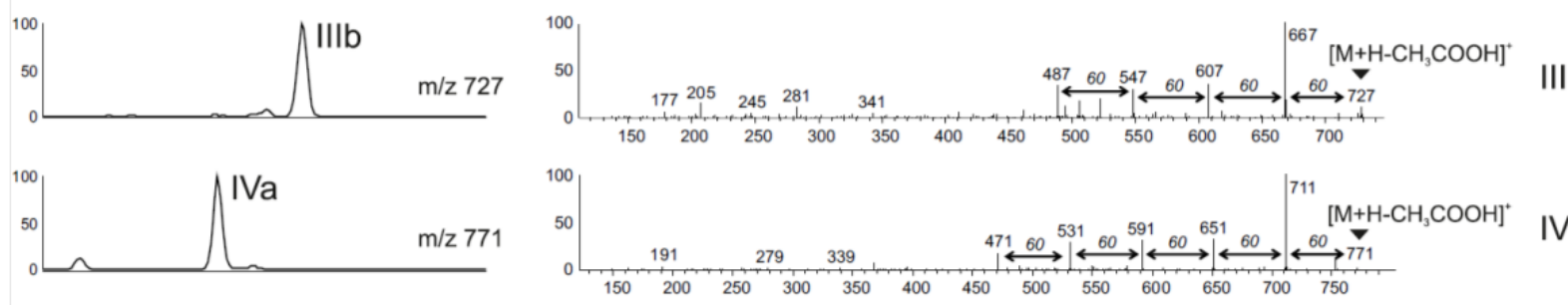

IVa
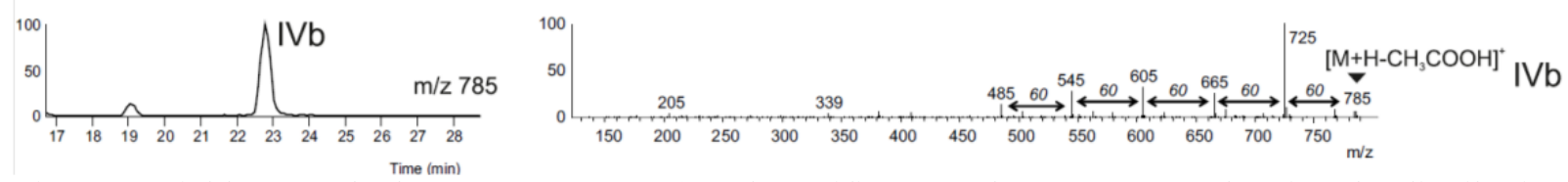

Fig. 4. Partial base peak chromatogram (BPC) and specific mass chromatograms showing the distribution of BHPs in enrichment culture Ooij-2 as revealed LC-APCI-MS analysis, including characteristic APCI $\mathrm{MS}^{2}$ spectra of all six hopanepolyols (analysed as their acetyl-derivatives). Sequential loss of four, five and six acetyl groups is typical for the BHP-tetrol, -pentol and -hexol, respectively. Further fragmentation results in loss of 192 or 206 , and a product with $\mathrm{m} / \mathrm{z} 191$ or 205 , for the BHPs without and with an additional methyl group at the A-ring, respectively. Numbers refer to structures depicted in Fig. 1.

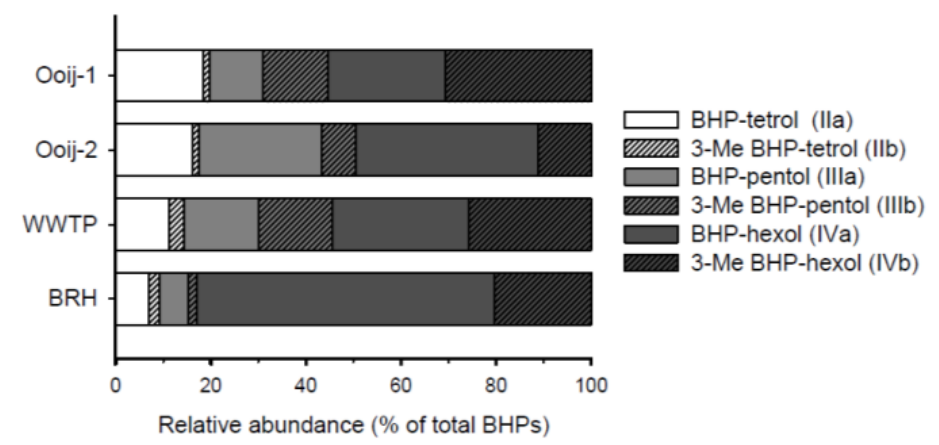

Fig. 5. The relative abundance of the different BHPs as percentage of the total BHPs, derived from LCMS data. Equivalent response factors for all BHPs were assumed as standards are not available. Numbers refer to structures depicted in Fig. 1. 


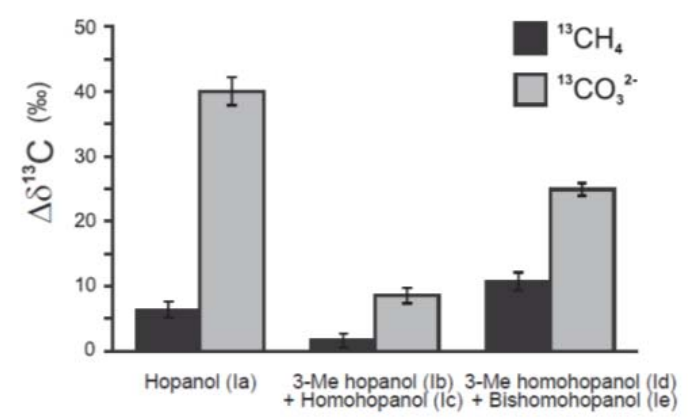

Fig. $6 .{ }^{13} \mathrm{C}$ enrichment of $M$. oxyfera hopanols (analysed as TMS derivatives) generated by periodic acid degradation of enrichment culture Ooij-1 after incubation with ${ }^{13} \mathrm{C}$-labeled $\mathrm{CH}_{4}$ or bicarbonate. Due to coelution of the hopanols, isotopic signatures cannot be distinguished for all individual hopanoids. The abundance of the 3-methyl bishomohopanol If was too low to accurately determine its stable carbon isotopic composition. Error bars indicate the standard error, based on duplicate analyses of two experimental replicates. Numbers refer to structures depicted in Fig. 1.

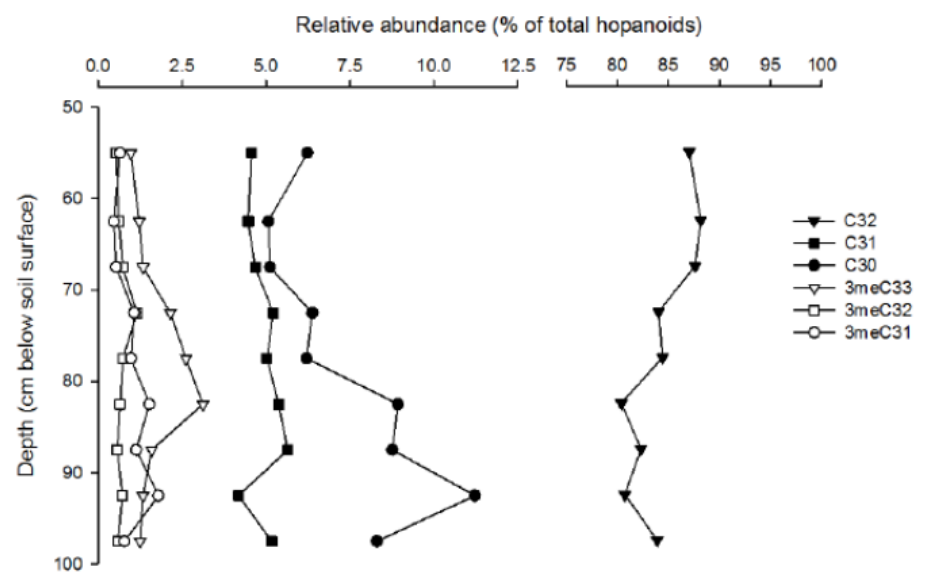

Fig. 7. Relative abundance of $\mathrm{C}_{30}, \mathrm{C}_{31}$ and $\mathrm{C}_{32}$ hopanols and their 3-methyl derivatives in the Brunssummerheide peat profile. Hopanols were quantified by GC-SIM-MS analyses of samples after periodic acid degradation. Numbers refer to structures depicted in Fig. 1. 